\title{
Scale-dependent variation in competitive ability among encrusting Arctic species
}

\author{
David K. A. Barnes ${ }^{1, *}$, Piotr Kuklinski ${ }^{2,3}$ \\ ${ }^{1}$ British Antarctic Survey, High Cross, Madingley Road, Cambridge CB3 0ET, UK \\ ${ }^{2}$ University Courses at Svalbard (UNIS), Longyearbyen 9171, Spitsbergen, Norway \\ ${ }^{3}$ Institute of Oceanology, Polish Academy of Sciences, Marine Ecology Department, ul. Powstancow Warszawy 55, Poland
}

\begin{abstract}
Finding evidence for climate change in the sea has been less easy than on land. As iceloading of nearshore waters (through ice sheet collapses) seems a most likely signal of climate warming, we looked at communities likely to be affected by changing disturbance, i.e. those encrusting boulders in shallow water. The structures of such assemblages at high latitude are highly hierarchical in which if uninterrupted by disturbance (ice-scour) succession would lead to domination by just a single species. However, unless pecking orders from place to place involve the same specific species, with the same competitive rankings, monopolisation will remain only local. To see how pecking orders varied, we examined variability in competitive performance of common species in a high Arctic lithophillic assemblage at several spatial scales. These were sampled $10^{1}, 10^{3}$ and $10^{5} \mathrm{~m}$ apart on the west coast of Spitsbergen, and $10^{6} \mathrm{~m}$ apart, achieved by sampling southern Iceland and the Faeroe islands. We found that higher taxonomic membership was the major factor determining overgrowth performance of species. Overgrowth performance of each study species changed relatively little between samples, the same good competitors being top performers in any samples where they occurred. Overgrowth performance of each study species was also most similar in samples at the smallest spatial scale. Apart from this, the performance of each study species did not, however, become more dissimilar with increasing distance between samples. Most noteworthy was that susceptibility to variation in overgrowth performance at the regional $10^{5} \mathrm{~m}$ scale altered with competitive ranking, i.e. pioneer and dominant species lost and won nearly all encounters respectively, wherever they were. The performance of mid-ranking species was much more variable. These results suggest that whilst the patterns of succession may differ from place to place, the end results will not. Our study provides data to support the theory that appreciation of scale is crucial to understanding community structure, diversity and potential for response to climate change. If ice-loading (disturbance) in polar waters does decrease, we suggest from our findings that a very small number of encrusting species may monopolise large areas of the shallows. Before this, though, we predict that different mid-ranked species will become more common from site to site, with limited reduction of ice (disturbance) increasing regional diversity.
\end{abstract}

KEY WORDS: Competitive rank · Overgrowth $\cdot$ Community structure $\cdot$ Transitivity

\section{INTRODUCTION}

Animals compete for a share of resources. Competition for mates is nearly always between those of the same gender within a species; the definition of a species makes this the case (but see Kolding 1986). In contrast, competition for food can involve different gen- ders and completely different types of animal fighting for resources (Brown \& Davidson 1977, Diamond 1987). As Darwin (1859) thought, though, it seems likely that competition for food typically involves closely related or similar competitors. Competition for space, as for food, can involve very different types of organism, even representatives of different kingdoms (Hochberg 
\& Lawton 1990). This is especially obvious along rocky littoral and sublittoral zones. There is a wide range of factors which may influence the outcome of contests between 2 shore competitors, such as encounter angle, height, size and various morphological characteristics or even non-contact interactions (Jackson 1979, Schoener 1983, Menge \& Sutherland 1987, Todd \& Turner 1988). Many studies have found that competition between marine benthos often ends up with one species winning in one place, but losing somewhere else (Jackson \& Buss 1975, Russ 1982, Chornesky 1989, Tanner 1997). The result of such encounters, even with intense competition, is that no particular species gains the upper hand, and monopolises areas. Nevertheless, strict hierarchies do exist, for example both within species for mates (Clutton-Brock et al. 1979) and in high latitude encrusting communities for space (Barnes 2002a). Without ice-scour around polar shores or other agents of disturbance, e.g. logs (Dayton 1971) or predators (Paine 1974), at some lower latitudes succession is determinate. The end product of succession is that top competitors almost completely cover shorelines.

Like encrusting lithophyllic assemblages in Antarctic waters, the single site investigated in the Arctic to date has been found to be highly hierarchical (Barnes \& Kuklinski 2003). Wherever these assemblages are protected from disturbance, a predictable succession of species takes place leading to local domination by the most superior competitor (Fig. 2. in Barnes 2002b). These assemblages do, however, receive a battering by ice and waves generated by the high wind speeds that typify high latitudes. Without this locally catastrophic disturbance, will a few species start to monopolise polar coastlines (Barnes 2002b)? This question is becoming increasingly important in the context of unprecedented rates of climate change at polar latitudes (Hansen et al. 1999, Serreze et al. 2000, Armstrong \& Brodzik 2001, Quale et al. 2002). Highlatitude terrestrial organisms have already shown substantial responses to climate change (Fowbert \& Smith 1994 Walther et al. 2002). These range from increases in population sizes and changes in distributions (e.g. in flowering plants, see Fowbert \& Smith 1994) to changes in measurable ecophysiological variables (e.g. water content in springtails, Convey et al. 2003) and biochemistry (e.g. protective pigments in mosses, Newsham et al. 2002). Evidence of responses to climate change by terrestrial polar organisms has recently been reviewed by Convey (2003). In the sea, however, finding evidence for climate change is less easy, due to a potentially large buffering effect. The predictions of climate models for oceans include confidence intervals so large that they encompass no measurable change over the next century (Murphy \& Mitchell 1995). We approached this question by formu- lating a number of hypotheses to test in a high Arctic lithophillic assemblage, which was species-rich but mainly composed of bryozoans. High-latitude assemblages may be hierarchical but unless the same specific species dominate at different places, monopolisation will remain only local. Understanding the main influences and outcomes of high-latitude competition and how these vary with scale should enable us to predict whether the same or different species would dominate from place to place.

In this study we investigate the performance of individual encrusting species in interference competition on the east coast of Spitsbergen, Svalbard ( 77 to $79^{\circ} \mathrm{N}$ ) as well as those on rocks in southern Iceland and in the southern parts of the Faeroe Islands. We hypothesised that (1) taxonomic membership would be the major factor determining overgrowth performance of species (most studies in the literature suggest that ascidians and sponges beat bryozoans, which all beat polychaetes and barnacles; see Quinn 1982, Russ 1982, Nandakumar 1995); (2) overgrowth performance of each study species does not change with species identity; good competitors are good everywhere; (3) overgrowth performance of each study species would become more dissimilar with distance apart of samples; and (4) competitive ranking of study species would not alter susceptibility to variation in overgrowth performance between sites. Finally, we compare the overgrowth performance of a number of common encrusting species in Spitsbergen waters with the performance of the same species in Iceland, the Faeroe Islands, Alaska, Scotland and Ireland, using data from the literature.

\section{MATERIALS AND METHODS}

Study area and species. Boulders were collected in July 2002 from the west coast of Spitsbergen Island (in the Svalbard Archipelago) in the high Arctic. Within this area, we selected 2 study localities $\geq 100 \mathrm{~km}$ apart: Kongsfjord $\left(79^{\circ} \mathrm{N}\right)$ and Horsund $\left(77^{\circ} \mathrm{N}\right)$. Within each of these 2 localities 3 sites were chosen, each $\geq 1 \mathrm{~km}$ apart. At each site $\geq 25$ boulder samples were taken $(\geq 10 \mathrm{~cm}$ apart) at 2 spots, which were $\geq 10 \mathrm{~m}$ apart. The sites were $\mathrm{K} 1\left(79^{\circ} 01.8 \mathrm{~N}, 11^{\circ} 49.8 \mathrm{E}\right), \mathrm{K} 2\left(78^{\circ} 59.5 \mathrm{~N}, 11^{\circ} 58.9 \mathrm{E}\right)$ and $\mathrm{K} 3\left(78^{\circ} 58.5 \mathrm{~N}, 11^{\circ} 29.8 \mathrm{E}\right)$ at Kongsfjord and $\mathrm{H} 1$ $\left(77^{\circ} 00.8 \mathrm{~N}, 15^{\circ} 33.3 \mathrm{E}\right), \mathrm{H} 2\left(76^{\circ} 56.8 \mathrm{~N}, 15^{\circ} 48.4 \mathrm{E}\right)$ and H3 $\left(76^{\circ} 57.4 \mathrm{~N}, 15^{\circ} 55.6 \mathrm{E}\right)$ at Horsund (Fig. 1). In each case samples were collected from the intertidal, 6 and $12 \mathrm{~m}$ depths. Samples were, therefore, collected at a variety of scales. Adjacent sampling scales differed by approximately 2 orders of magnitude. As well as at Svalbard, samples were also collected at 2 subarctic sites: southern Iceland, near Reykjavik $\left(64.1^{\circ} \mathrm{N}\right.$, 
$22.2^{\circ} \mathrm{W}$ ), and in the southern Faeroe Islands, near Torshavn $\left(62.05^{\circ} \mathrm{N}, 6.90^{\circ} \mathrm{W}\right)$. These additional collections were carried out at a similar time (August 2002), in similar protocol, enabling comparisons at the $10^{6} \mathrm{~m}$ scale with Spitsbergen material. Only intertidal samples were collected in Iceland. Intertidal, 6 and $12 \mathrm{~m}$ samples were collected in the Faeroe Islands.

The samples from Spitsbergen all experienced similar environmental conditions, such as summer icescour and winter fast-ice (frozen sea surface). Winter fast-ice is less common and longer lived from the inner fjord to the mouth (Węsławski et al. 1988). Sea temperature in July was $\sim 3^{\circ} \mathrm{C}$ in all areas (annual variation approximately -1.8 to $+4^{\circ} \mathrm{C}$ ). The near-bottom salinity regime is even more stable, varying from just 33 to $34 \mathrm{psu}$. At the surface and on the shore, salinity can change rapidly with the melt around June (32 to 25 psu; see Swerpel 1985, Węsławski et al. 1988). There is a substantial suite of potential competitors, except in the intertidal, which is characterised by a depauperate fauna (Węsławski et al. 1993, Kuklinski 2001). Potential major competitors for space on boulders in both regions included balanomorph barnacles, cheilostomatid bryozoans, cyclostomatid bryozoans, colonial ascidians, tubicolous polychaetes and occasional Calcarea and demosponge Porifera (sponges).

Protocol. Collections were made at each of the 3 depths: intertidal (extreme low water spring tide level), 6 and $12 \mathrm{~m}$, at each site. Each collection consisted of at least 25 (randomly selected) boulders, together totalling $6900 \mathrm{~cm}^{2}$ surface area $( \pm$ SE 244.7$)$. The identity of all colonists involved in interactions (aggressive encounters) and the outcome between each species pair was recorded. Contact between 2 or more recruits was designated as an interaction if both were live and $5 \%$ or more of the organism periphery was affected. Interactions were defined and scored as overgrowth (i.e. a win for one of the competitors), following established criteria (Sebens 1986, Tanaka \& Nandakumar 1994, Barnes 2002a). An example of previous criteria is whether the loser's feeding apparatus was obscured (thus preventing activity). Encounters were termed as tied when mutual (equal) overgrowth took place, or skeletal build-up but no overgrowth (frequently referred to as a standoff) occurred. Data were arranged into species-pair contact matrices, but only competitor species involved in at least 10 interactions were included. A number of features of the data were calculated: (1) the overgrowth performance of each competitor species at each site (number of wins/total number of interactions), (2) the top 3 dominant species at each site, (3) similarity (using Bray-Curtis scores) of overgrowth performance between scales and between species. We were therefore asking whether the competitive performance of species was more similar in as- semblages close together than far apart, and whether good competitors varied more (or less) than poor ones.

We display the species-pair matrices in standard form (see Quinn 1982, Russ 1982, Turner \& Todd 1994, Nandakumar 1995, Barnes \& Kuklinksi 2003). This gives in each cell of the matrix the number of wins (and therefore losses: a win for A is a loss for B and vice versa) as well as tied outcomes for each of the 2 competitors. Matrices for 2 example replicates are shown for each of the 6 and $12 \mathrm{~m}$ samples to illustrate the structure of competition and how it varies. Data were, where necessary, arcsine-transformed prior to testing for normality and tested using GLM ANOVA. Many of the species were rare, so to avoid undue bias and to meet assumptions for ANOVA, species were not included in analyses unless they occurred in all sites and were involved in at least 8 interactions. To compare similarity of species performance in competition we first obtained Bray-Curtis scores. For analysis of data in this form, fully nested ANOVA (a typical method of analysis with spatial scale) is not appropriate, as it would not be possible to include species as a factor (species is not nested within the other factors). We used GLM ANOVA on similarity data (as the response) with species and scale as separate factors and then applied post-hoc Tukey tests to all possible pairings.

Comparison with data from the literature. We compared overall performance in overgrowth competition (win/loss scores in interactions) in species for which competition data were available from Scotland (Turner \& Todd 1994, D. K. A. Barnes unpubl.), Alaska (Barnes \& Dick 2000) and Ireland (Maughan 2000, Maughan \& Barnes 2001). These data were collected in similar ways from rocky nearshore boulder habitats and similar definitions of overgrowth were used.

\section{RESULTS}

\section{Dominant competitors}

Competition for space between encrusting macrofaunal species was common on sublittoral boulders of the high Arctic and subarctic sites studied. At the Spitsbergen study areas alone, there were 32 common competitors and a further 17 minor species (these were either common at just 1 site or rare across sites; Table 1). These were diverse, belonging to 5 phyla and 7 classes, though most were gymnolaemate bryozoans. The complexity of competition is illustrated by the number of different pair-wise interactions, which occurred between competitors present in each sample (Tables $2 \& 3$ ). Furthermore, competitor species were present to different degrees in each sample and met other competitors 
on different numbers of occasions in different samples, so generalities of species trends were not straightforward. Of the possible factors investigated in this study, location, depth and rock-size were found to be insignificant influences on competitive performance of randomly chosen species (Table 4). The identity of the chosen species was a significant factor, but this explained little variability. The highest taxonomic membership in our test, Class was both highly significant and explained the majority of variability in competitor performance (but a similar result was gained when the analysis was repeated at the Phylum level).

\section{Geographic variability of dominant species}

The top 3 competitors at each site/depth combination did vary, but not much (Table 5). In $>80 \%$ of sampled assemblages the bryozoans Tegella retroversa Kluge, T. arctica or the ascidian Diplosoma sp. were the dominant species. There was less variability of dominant species at 6 than $12 \mathrm{~m}$; in the shallower depth, the same species was dominant in both samples at 4 of the 6 sites. At 12 $\mathrm{m}$, in contrast, only at 2 of the sites were both samples dominated by the same species, and the dominant species differed between these 2 sites. It would therefore seem that the best competitors were typically superior wherever they were, within our study area.

There was substantial variability in the number and type of competitors and their frequency of meeting each other (e.g. Tables 2 \& 3). Despite this the overall performance of most species, as well as the best competitors (Table 4), varied little between sites (Table 6). Some, e.g. the bryozoan Callopora sp., did vary substantially from 15 to $84 \%$ of interactions won. Other than taxon membership, another obvious potential influence on variability in overgrowth performance of study species between samples was the distance apart of such samples. The performance of individual spe- cies was more similar between samples $\left(10^{1} \mathrm{~m}\right.$ scale $)$ than at other scales (post-hoc Tukey tests all $\mathrm{p}<0.001$ following GLM ANOVA, see Table 7). The level of similarity $(87.56 \pm 5.47 \%)$ between samples was significantly higher than that between sites, localities or regions, which were each not significantly different from one another. Species was, however, a significant factor. Many species showed no spatial trend whilst the performance of others became increasingly dissimilar with distance apart up to locality (Fig. 1). Inclusion of different regions $\left(10^{6} \mathrm{~m}\right.$ scale) similarly showed only patterns in a few species and no overall trend (Fig. 2). The performance of some species (e.g. Electra arctica Borg and Tegella armifera Hincks) was even more similar between samples from different regions than those within the same site. In contrast, the performance of others (e.g. Celleporella hyalina Linnaeus 
and Cribrilina annulata Fabricius) became progressively more dissimilar with distance apart of the samples. Some species showed very similar performance in spatial competition within Atlantic arctic, subarctic and temperate regions, but quite dissimilar win/total interaction score in the Pacific subarctic (Table 8).

\section{Similarity of performance with competitive rank}

Both dominant competitors (e.g. ascidians, demosponges and bryozoans of the genus Tegella) and poorest competitors (e.g. thinly calcified cheilostomatid bryozoans Celleporella hyalina and Cylindroporella

Table 2. Matrix of competitive interactions between encrusting species in 2 samples from Arctic study site K1 (Spitsbergen) at $6 \mathrm{~m}$ depth. Data are displayed in standard form: see Turner \& Todd (1994), Barnes (2002). If rows = Competitor A and columns $=$ Competitor B, for each cell the top left, top right and bottom left data give, respectively, the number of ties between Species A and B, wins by B (=losses by A) and wins by A (=losses by B). Number in the bottom right of each cell is the total number of observed interactions for that species pair. For full species names see Table 1

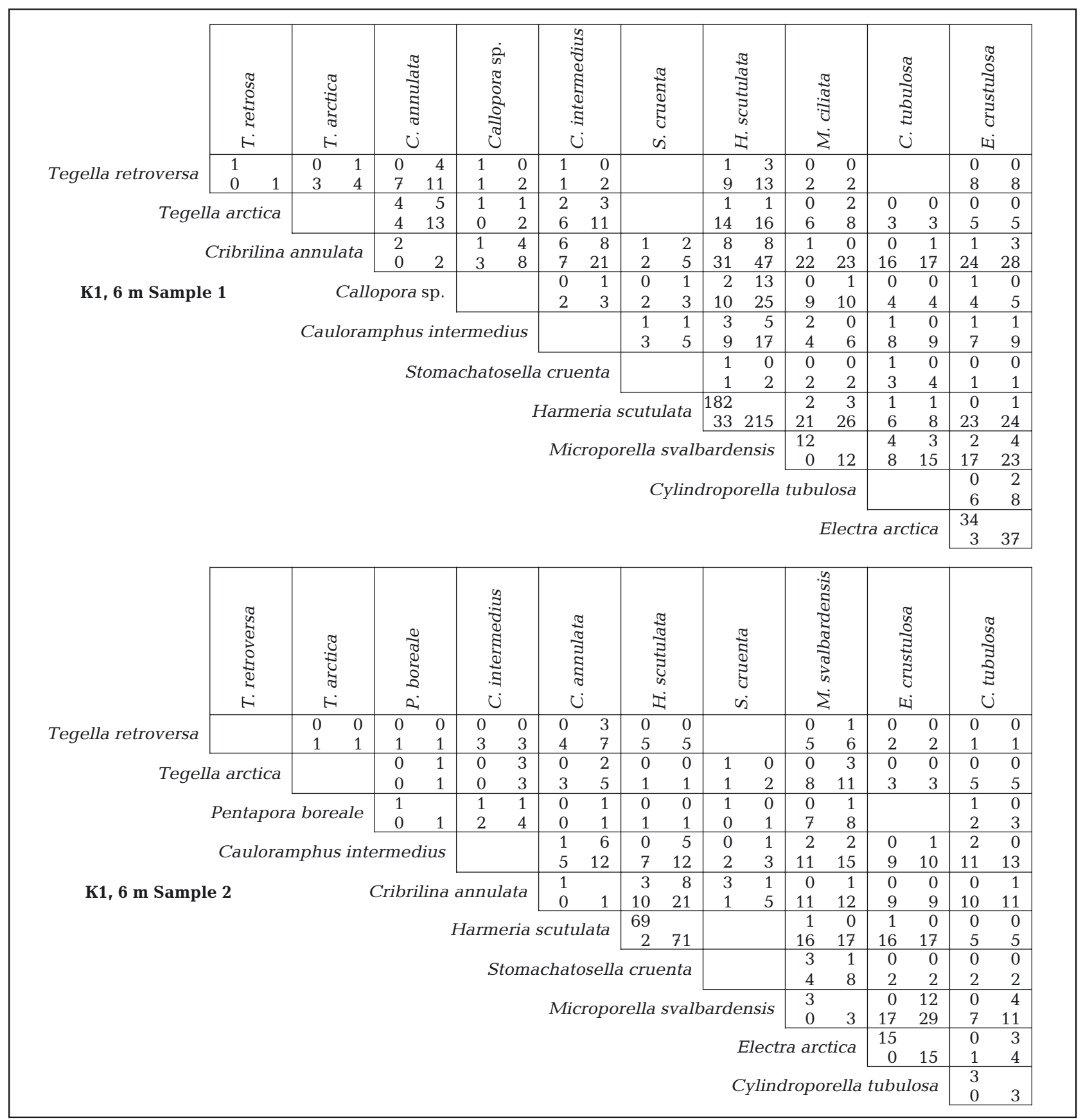


Table 3. Matrix of competitive interactions between encrusting species at each of 2 samples from Arctic study site K1 (Spitsbergen) at $12 \mathrm{~m}$ depth. Data are displayed as in Table 2

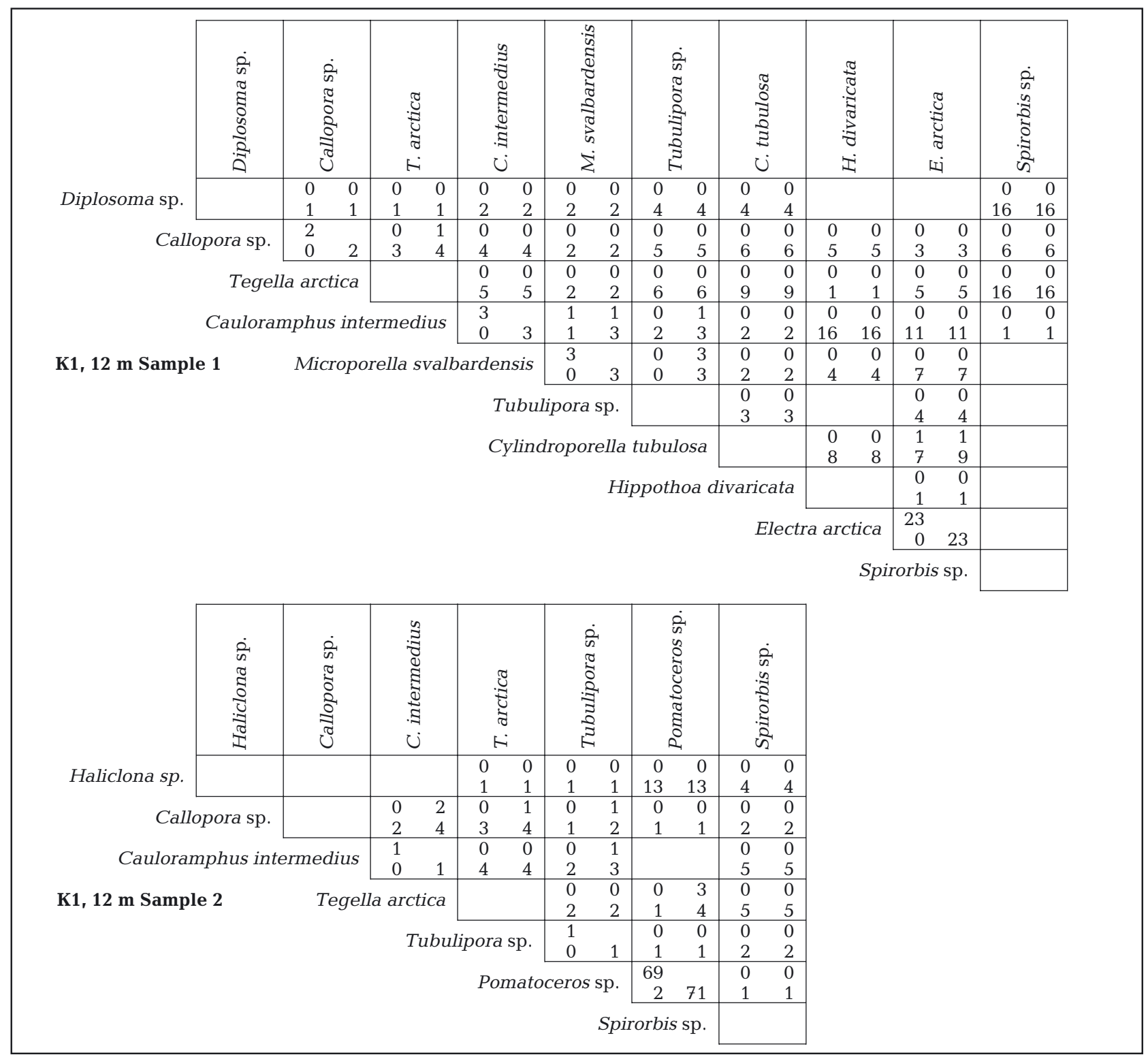

tubulosa Norman, barnacles and tubicolous polychaetes) seem to perform similarly in wins/total encounters. On plotting between-region similarity in performance of study species, we found that this was true relative to mid-ranked competitors (Fig. 3). Thus our data supported a parabolic relationship $\left(\mathrm{r}^{2}=0.83\right.$, ANOVA, $\left.F_{1}=31.8, \mathrm{p}<0.001\right)$ between how much competitors differed in performance and their rank. Those at extremes (very weak or strong spatial competitors) varied little $(\sim 10 \%)$ between regions. The mean difference in competitive performance with space increased, peaking at about $50 \%$.
Table 4. GLM ANOVA of factors influencing overgrowth performance of competitors at Spitsbergen. Source: source of error, DF: degrees of freedom, Seq SS: sequential sums of squares, Adj SS: adjusted sums of squares, Adj MS: adjusted mean square, F: test statistic F-ratio and p: probability. *Significant results

\begin{tabular}{|lrrrrrr|}
\hline Source & DF & Seq SS & Adj SS & Adj MS & $F$ & $\mathrm{p}$ \\
\hline Class & 5 & 43.7528 & 43.7528 & 8.7506 & 987.85 & $0.000^{*}$ \\
Location & 1 & 0.0250 & 0.0250 & 0.0250 & 2.83 & 0.094 \\
Depth & 1 & 0.0000 & 0.0000 & 0.0000 & 0.00 & 0.973 \\
Rocksize & 2 & 0.0200 & 0.0200 & 0.0100 & 1.13 & 0.325 \\
Species & 1 & 0.1106 & 0.1106 & 0.1106 & 12.49 & $0.000^{*}$ \\
Error & 277 & 2.4537 & 2.4537 & 0.0089 & & \\
Total & 287 & 46.3622 & & & & \\
\hline
\end{tabular}


Table 5. Dominant species with highest performance (total number of wins/total number of interactions) in competition with locality, site, sample and depth at Spitsbergen. Localities are Horsund $(\mathrm{H})$ and Kongsfjord $(\mathrm{K})$, and the sites at each are termed 1, 2 and 3. Most dominant species is leftmost in each cell. Abbreviations are as follows: Cauloramphus intermedius (Ci), Diplosoma sp. (Dp), Escharella ventricosa (Ev), Haliclona sp. (Ha), Micropora svalbardensis (Ms), Pentapora sp. nov. (Ps), Rhamphostomella bilaminata (Rb), Schizoporella auriculata (Sa), Schizoporella crustacea (Sc), Schizoporella pachystega (Sp), Tegella armifera (Ta), Tegella arctica (Tr) and Tegella retroversa (Tv)

\begin{tabular}{|lcccccc|}
\hline & H1 & H2 & H3 & K1 & K2 & K3 \\
\hline 6 m Sample 1 & Tv Sa Ta & Tv Ta Tr & Ev Tr Ta & Tv Tr Cl & Ps Ta Tr & Dp Sc Ms \\
6 m Sample 2 & Tv Ta Sz & Tv Ta Tr & Tv Tr Ta & Tv Cl Ta & Ta Tr Ca & Dp Ha Ta \\
12 m Sample 1 & Dp Sp Tv & Tv Ta Tr & Ta Tv Tr & Dp Cl Ta & Ha Ta Ps & Dp Tv Ta \\
12 m Sample 2 & Tv Rb Ta & Tv Cl Ta & Tv Ta Tr & Ha Sc Cl & Ta Ps Ci & Dp Ha Ps \\
\hline
\end{tabular}

bance by ice-scour seems likely to be near random, though increasing with depth (Barnes 1999). It is not surprising, given this disturbance, geological youth (Dunton 1992), and reduced energy input (Allen et al. 2002) amongst other proposed factors, that Arctic seas are typically depauperate (e.g. gastropod, Roy et al. 1998; bivalves, Crame 2000). However there is a strong and recent signal of regionalised warming in the Arctic (Serreze et al. 2000, Armstrong \& Brodzik 2001). This is likely to have a major influence on levels of disturbance in high-

\section{DISCUSSION}

Shallow polar, and particularly Arctic, waters are likely to be amongst the most disturbed habitats anywhere (Gutt et al. 1996, Gutt 2001). On some timescales this is predictable. A calm winter period when the sea is covered with fast-ice alternates with a period of open water, when shallow benthos is exposed to severe wave action, ice-scour, freshwater runoff and locally anoxia and pollution (Dayton 1990). On larger timescales, higher latitudes have been subjected to a series of ice ages and sea temperature fluctuations, which are less predictable. At small temporal and spatial scales too, the frequency and intensity of distur- latitude coastal waters, ice sheet collapses in the short term must increase potential for scouring. Ultimately, even in the short term, the disappearance of coastal ice should drastically reduce disturbance to communities such as those we have studied here. The boulder fields of shallow Arctic seas can have abundant encrusting faunas, but because of current disturbance regimes, they are mainly composed of pioneer species (Kuklinski 2001, Barnes \& Kuklinski 2003). We consider our results to link competition, disturbance, climate change (in the context of changing ice levels in the water) and the importance of consideration of spatial scale.

We report here a simple data set: a series of pair-wise interactions between Arctic species in samples col-

Table 6. Performance of Spitsbergen encrusting species at each of the study sites. Data are the number of wins/total interactions for each species at each site shown with sample size $n$ as superscript. Localities are Horsund (H) and Kongsfjord (K) and the sites at each are termed 1, 2 and 3 (see 'Materials and methods' for latitudes and longitudes of sites)

\begin{tabular}{|c|c|c|c|c|c|c|}
\hline Species & H1 & $\mathrm{H} 2$ & H3 & K1 & K2 & K3 \\
\hline Callopora lata & & & $0.75^{8}$ & $0.81^{85}$ & $0.72^{11}$ & \\
\hline Callopora sp. & $0.5^{29}$ & $0.84^{19}$ & $0.20^{20}$ & $0.39^{73}$ & $0.15^{8}$ & $0.55^{11}$ \\
\hline Cauloramphus intermedius & $0.48^{132}$ & $0.58^{182}$ & $0.35^{137}$ & $0.64^{249}$ & $0.42^{47}$ & $0.35^{41}$ \\
\hline Celleporella hyalina & $0.0^{7}$ & $0.0^{5}$ & $0.0^{4}$ & $0.15^{8}$ & $0.0^{2}$ & $0.0^{9}$ \\
\hline Cribrilina annulata & $0.56^{148}$ & $0.76^{24}$ & $0.4^{122}$ & $0.6^{278}$ & $0.5^{86}$ & $0.55^{20}$ \\
\hline Cylindroporella tubulosa & $0.21^{68}$ & $0.0^{9}$ & $0.0^{12}$ & $0.18^{201}$ & $0.07^{55}$ & $0.1^{28}$ \\
\hline Diplosoma sp. & $1.0^{45}$ & $1.0^{33}$ & & $1.0^{32}$ & & $1.0^{40}$ \\
\hline Electra arctica & $0.02^{158}$ & $0.0^{21}$ & $0.0^{71}$ & $0.15^{236}$ & $0.08^{15}$ & $0.0^{10}$ \\
\hline Harmeria scutulata & $0.42^{270}$ & $0.17^{489}$ & $0.27^{320}$ & $0.51^{289}$ & $0.25^{139}$ & \\
\hline Microporella svalbardensis & & & $0.0^{3}$ & $0.37^{303}$ & $0.33^{16}$ & $0.51^{122}$ \\
\hline Pentapora boreale & $0.47^{11}$ & & $0.44^{18}$ & $0.67^{54}$ & $0.74^{36}$ & $0.75^{48}$ \\
\hline Patinella sp. & $0.22^{20}$ & $0.55^{20}$ & $0.5^{4}$ & $0.49^{6}$ & $0.3^{3}$ & $0.37^{8}$ \\
\hline Porella alba & $0.0^{12}$ & & $0.0^{3}$ & $0.32^{25}$ & & \\
\hline Schizoporella crustulosa & $0.82^{82}$ & & & $1.0^{5}$ & & \\
\hline Semibalanus balanoides & $0.0^{129}$ & $0.0^{33}$ & $0.0^{53}$ & $0.0^{7}$ & $0.3^{3}$ & $0.0^{8}$ \\
\hline Spirorbis sp. & $0.0^{42}$ & $0.0^{20}$ & $0.0^{6}$ & $0.0^{99}$ & $0.0^{40}$ & $0.01^{97}$ \\
\hline Stomachetosella cruenta & $0.59^{47}$ & $0.33^{9}$ & $0.43^{36}$ & $0.5^{59}$ & $0.13^{8}$ & $0.55^{27}$ \\
\hline Tegella armifera & $0.77^{71}$ & $0.76^{76}$ & $0.59^{197}$ & $0.63^{8}$ & $0.47^{14}$ & $0.67^{3}$ \\
\hline Tegella arctica & $0.84^{236}$ & $0.82^{155}$ & $0.59^{237}$ & $0.71^{202}$ & $0.76^{80}$ & $0.90^{69}$ \\
\hline Tegella retroversa & $0.91^{188}$ & $0.91^{180}$ & $0.66^{230}$ & $0.87^{71}$ & & $1.0^{6}$ \\
\hline Tubulipora sp. & $0.0^{3}$ & & & $0.37^{57}$ & $0.5^{4}$ & $0.3^{61}$ \\
\hline
\end{tabular}


Table 7. GLM ANOVA of factors influencing similarity of overgrowth performance of competitors at Spitsbergen. Source: source of error, DF: degrees of freedom, Seq SS: sequential sums of squares, Adj SS: adjusted sums of squares, Adj MS: adjusted mean square, $F$ : test statistic $F$ ratio, p: probability. ${ }^{*}$ Significant results, post-hoc Tukey tests are shown below

\begin{tabular}{|c|c|c|c|c|c|c|}
\hline Source & DF & Seq SS & Adj SS & Adj MS & $F$ & $\mathrm{p}$ \\
\hline Species & 7 & 4243.4 & 4243.4 & 606.2 & 31.9 & $0.000^{*}$ \\
\hline Scale & 3 & 895.1 & 895.1 & 298.4 & 15.7 & $0.000^{*}$ \\
\hline Error & 117 & 2223.6 & 2223.6 & 19.0 & & \\
\hline Total & 127 & 7362.1 & & & & \\
\hline \multicolumn{7}{|c|}{ Mean similarity among levels of scale } \\
\hline Scale & Mean & $\mathrm{SD}$ & & & & \\
\hline $10^{1}$ & 87.56 & 5.47 & & & & \\
\hline $10^{3}$ & 82.91 & 7.94 & & & & \\
\hline $10^{5}$ & 80.66 & 8.21 & & & & \\
\hline $10^{6}$ & 81.66 & 6.95 & & & & \\
\hline \multicolumn{7}{|c|}{ Post-hoc Tukey pair-wise comparisons among levels of scale } \\
\hline Scale & \multicolumn{2}{|c|}{$\begin{array}{l}\text { Difference } \\
\text { of means }\end{array}$} & $\begin{array}{c}\text { SE of } \\
\text { difference }\end{array}$ & $t$ & \multicolumn{2}{|c|}{$\mathrm{p}$} \\
\hline \multicolumn{2}{|c|}{$10^{1}$ vs $10^{3}$} & 4.66 & 1.09 & 4.27 & \multicolumn{2}{|c|}{$0.000^{*}$} \\
\hline \multicolumn{2}{|c|}{$10^{1}$ vs $10^{5}$} & 6.91 & 1.09 & 6.34 & \multicolumn{2}{|c|}{$0.000^{*}$} \\
\hline \multicolumn{2}{|c|}{$10^{1}$ vs $10^{6}$} & 5.91 & 1.09 & 5.42 & \multicolumn{2}{|c|}{$0.000^{*}$} \\
\hline \multicolumn{2}{|c|}{$10^{3}$ vs $10^{5}$} & 2.25 & 1.09 & 2.06 & \multicolumn{2}{|c|}{0.171} \\
\hline \multicolumn{2}{|c|}{$10^{3}$ vs $10^{6}$} & 1.25 & 1.09 & 1.15 & \multicolumn{2}{|c|}{0.661} \\
\hline \multicolumn{2}{|c|}{$10^{5}$ vs $10^{6}$} & -1.00 & 1.09 & -0.92 & \multicolumn{2}{|c|}{0.795} \\
\hline
\end{tabular}

lected at different distances apart. However, competition at high-latitude is for the most part probably unimportant (Connell 1985, Roughgarden 1986, Menge \& Sutherland 1987), so what is the relevance of our study? In sheltered patches, polar competition is common and extremely hierarchical. Outcomes of interspecific meetings nearly always result in overgrowth of the loser and a species at the top of the pecking order beats all below (Barnes 2002a). Based on these findings, Barnes \& Kuklinski (2003) tested the predicted level of hierarchy for a high Arctic assemblage and found what was expected. This finding means relatively little on a larger scale however, because what happens at one site might be very different to what happens at another. This applies particularly to sites being of increasing distance apart. Even in a speciespoor environment like the shallow Arctic, each species competes with many others (MacArthur 1972), and these should vary from place to place. If the environment is patchy, which might be expected in a high polar shallow sea, an understanding of what happens across scales is crucial for any generalities being made. In this study we have systematically tried to explain the components of variability in competition, which

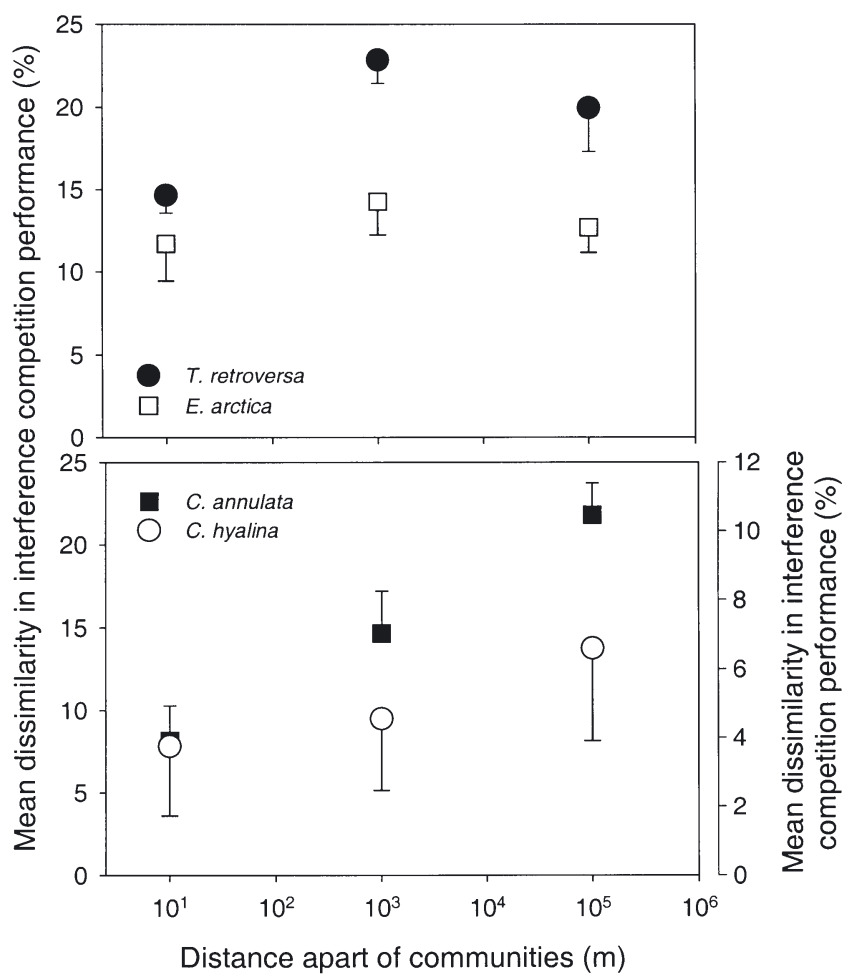

Fig. 1. Dissimilarity in performance in spatial competition with distance apart of samples, in coastal bryozoans at Spitsbergen. Dissimilarity values were obtained by comparing samples to others within the same site, between sites and between localities. Data for Celleporella hyalina are scaled by a right (offset) $y$-axis. Data are shown as mean $(n=8) \pm S E$

lead in turn to the possibility of making statements of generality and predictions based on changing disturbance.

Our first hypothesis concerned the identity of the competitor. The results we present show that species identity was a significant factor, but the main predictor of success was higher taxon membership (Table 4). Ascidians were the best space competitors, then demosponges (but both were rare), cheilostome bryozoans (intermediate in performance and common), cyclostome bryozoans (poor and rare) and lastly polychaete annelids, cirriped crustaceans and hydroid cnidarians (poor and common). Such a ranking has been found at lower latitudes (Quinn 1982, Russ 1982, Nandakumar 1995, Maughan \& Barnes 2000). The relative performance of higher taxa in time and space have, as a result, received a fair amount of scientific attention (Hochberg \& Lawton 1990, McKinney et al. 1998, Barnes 2002b). There have been, in contrast, few comparisons of species performance, especially in the sea.

Species should compete better in the middle of their ranges than at the edges (Connell 1961, Austin 1999), but little is known about how performance of individual species actually varies from place to place. If the 


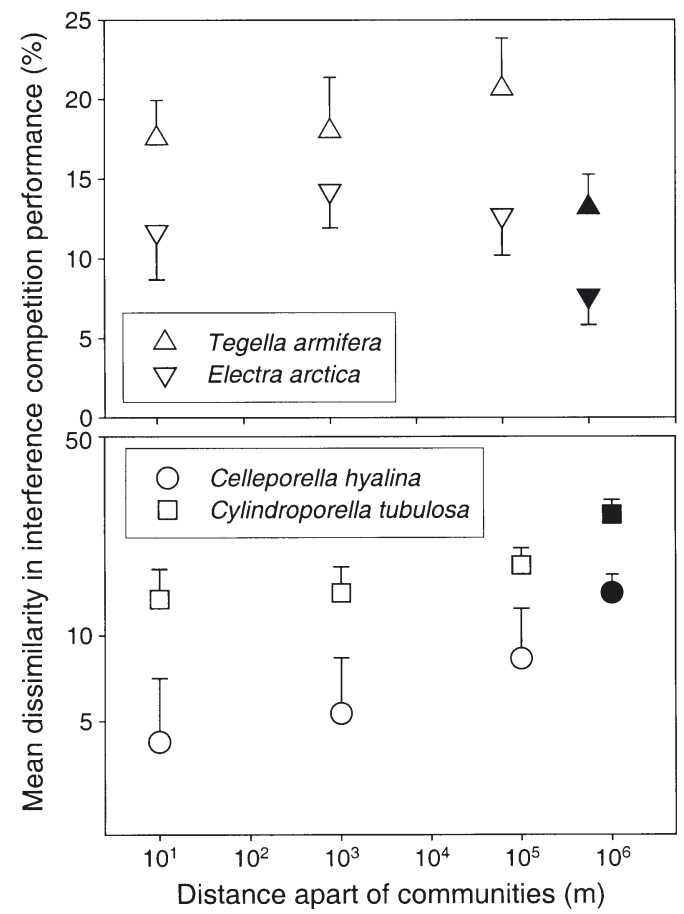

Fig. 2. Dissimilarity in performance in spatial competition with distance apart of samples, in coastal bryozoans in northern polar region (Spitsbergen, Iceland and the Faeroe

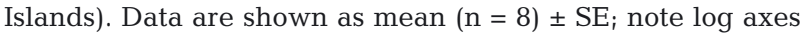
on lower plot. Legend to species is shown on the plot. Open symbols are Spitsbergen data; filled symbols are subarctic data

same species are at the top of the pecking order at multiple scales, then in conditions of reduced disturbance, such species would monopolise more than just local areas. We show that the identity of the top competitors does vary at $10^{1}, 10^{3}$ and $10^{5} \mathrm{~m}$ scales (Table 5), but not much. Just 2 species accounted for most of the dominant competitors in each sample. We suggest that these species are likely to be good indicators of

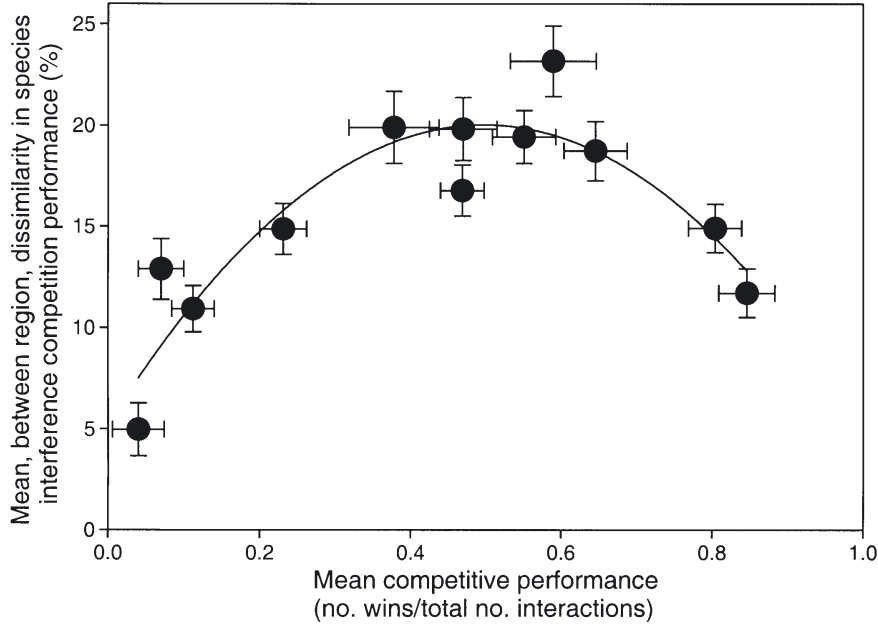

Fig. 3. Mean dissimilarity in performance in spatial competition (between region) with mean competitive performance in 12 bryozoan species at Spitsbergen. Each point represents mean values \pm SE for 1 species. Fitted line is a second-order (quadratic) regression with $\mathrm{r}^{2}=0.83$ and a significance of $\mathrm{p}<0.001\left(\right.$ ANOVA, $\left.F_{1}=31.8\right)$

organism response to reduction in disturbance to the Spitsbergen region, should (as seems likely) floating ice patterns change as a consequence of climate change. Given the potential differences between competitor number, identity and differences between sites, the performance of most study species was remarkably similar between sites (Table 6). Like the top competitors, the poorest were poor in every sample in which they were common enough to be assessed. As elsewhere in highly disturbed environments, they were often the, or amongst the, most abundant species (Dayton 1971, Paine 1979, Karlson 1983, Barnes \& Clarke 1998, Karlson 1999). Although overall variability in the performance of same species between samples was not large, we probed this data

Table 8. Performance (wins/total interactions) of encrusting species at high-latitude northern hemisphere regions. Data are shown as in Table 6. Data sources are present study except Alaska (Barnes \& Dick 2000), Scotland (Turner \& Todd 1994) and Ireland (B. Maughan unpubl.)

\begin{tabular}{|c|c|c|c|c|c|c|}
\hline Species & Spitsbergen & Iceland & Faeroe & Alaska & Scotland & Ireland \\
\hline Cauloramphus intermedius & $0.47^{788}$ & $0.33^{32}$ & $0.67^{12}$ & $0.51^{154}$ & & \\
\hline Celleporella hyalina & $0.04^{35}$ & $0.22^{19}$ & $0.07^{27}$ & $0.25^{584}$ & $0.15^{233}$ & $0.12^{52}$ \\
\hline Cribrilina annulata & $0.55^{658}$ & $0.55^{32}$ & $0.5^{8}$ & $0.29^{104}$ & $0.5^{16}$ & \\
\hline Cylindroporella tubulosa & $0.11^{368}$ & & & $0.25^{23}$ & & \\
\hline Electra arctica & $0.07^{512}$ & $0.10^{42}$ & & $0.15^{10}$ & & \\
\hline Microporella sp. & $0.44^{444}$ & & $0.34^{62}$ & $0.33^{404}$ & $0.41^{37}$ & $0.61^{146}$ \\
\hline Patinella sp. & $0.37^{61}$ & & $0.48^{44}$ & $0.26^{142}$ & & $0.4^{40}$ \\
\hline Tegella armifera & $0.65^{369}$ & & & $0.64^{170}$ & & \\
\hline Tegella arctica & $0.76^{979}$ & & & $0.62^{131}$ & & \\
\hline Tubulipora sp. & $0.41^{125}$ & $0.21^{20}$ & $0.25^{125}$ & & & $0.4^{152}$ \\
\hline
\end{tabular}


to investigate whether there might be significant (if small) trends in space.

Our third hypothesis, that overgrowth performance of study species would become more dissimilar with distance apart of samples, was partly supported. Competitive performance of species was most similar in samples from the same site (the smallest spatial scale investigated here). We found performance was significantly more similar within a site than at larger scales, but no differences in similarity at the larger scales of $10^{3}, 10^{5}$ and $10^{6} \mathrm{~m}$ (Table 7 ). Some individual species did show decreased similarity of performance over these scales, but even then only in 1 species, Celleporella hyalina, was this significant. So despite encompassing 4 spatial scales spanning $1 \mathrm{~m}$ to $1000 \mathrm{~km}$, we only detected local differences in mean competitive performance of species with distance apart. Yet our study did encompass the entire ranges for some Arctic species and was close to the known edge of others. There are a number of possible explanations for why we did not find changes on a larger scale in performance: (1) performance is so complex, with so many factors acting together, that a non-manipulative field study may not detect such differences; (2) we sampled randomly rather than in the centre and outer margins of ranges for selected species; (3) performance differences may not really be very big in these study species as we have already ascertained that a major, and unchanging, factor was higher taxon membership; (4) there is variability with distance, but it is masked by itself varying with another factor. We found that at least Explanation 4 was true: the masking factor was competitive rankings of species.

We found that the competitive ranking of study species altered susceptibility to variation in overgrowth performance in space (Fig. 3). Therefore Arctic assemblages comprise a few pioneer species, which lose virtually all competition for space wherever they are, and a few dominant species, which conversely win all competitive encounters. In between these extremes (where the performance of most species must lie), the performance and rankings of species are more variable and so, consequently, will be succession. This result is a good example of the need for appreciation of patterns with scale to understand community structure and diversity. At local scales, potential for diversity in the absence of disturbance seems very different with latitude. At lower latitudes, particularly in the tropics, studies of benthic interactions at single sites have usually revealed highly intransitive (non-hierarchical) networks. In these, encounters sometimes result in Species A beating $B, B$ beating $A$, or $A$ and $B$ reaching a standoff (or tie) (Quinn 1982, Russ 1982, Tanaka \& Nandakumar 1994). These repeated reversals in outcome between species-pairs and similarity of rank between most competitors even occur when all study competitors have the same higher taxon membership (Buss \& Jackson 1979, Chornesky 1989, Tanner 1997). Encrusting assemblages at a given high-latitude site are regulated by strict hierarchies (Barnes 2002a, Barnes \& Kuklinski 2003). If highly disturbed or undisturbed, these hierarchies would probably be characterised by very low levels of species richness compared with assemblages organised in networks (Karlson \& Jackson 1981). Thus this is a clear example of the intermediate disturbance hypothesis (Connell 1978): high disturbance results in abundance of a few pioneers (such as Harmeria scutulata). Low disturbance in protected areas results in abundance of a few overgrowth dominants (such as Tegella retroversa) or in the Antarctic (Beania errecta, Barnes 2002b). Between these extremes a wide range of intermediate competitors flourish (on the undersurfaces of the larger, less easily disturbed boulders). Each sampling site in the present study was characterised by hierarchies of bryozoans. Although these hierarchies were composed of similar species assemblages, the ranking (or ordering) of the species within each hierarchy was different (such that even dominant species differed). So when considered at larger scales (e.g. $\mathrm{km}$ to $100 \mathrm{~s}$ of $\mathrm{km}$ ), these hierarchies may be viewed collectively as a network. A network can be formed when A beats B, and A and $B$ beat $C$ (i.e. a very localised hierarchy) in one place, if beside it in another place, B beats A, and B and C beat A (Tanaka \& Nadakumar 1994). This is analogous to what we have found, except the 'places' are $\mathrm{km}$ apart rather than $\mathrm{m}$ or $\mathrm{cm}$ as typically described. Scale-dependent richness is also a feature of tropical coral assemblages (see Karlson \& Cornell 1998).

In summary, we have found that the type of animal each competitor is mostly dictates the outcome of fights, but ultimately, that the same few species top the pecking order across scales. Most importantly, Arctic competition does not differ much from place to place, except at a very small scale, so we can generalise to the regional scale with some confidence. The context of our findings is linked to the regionalised warming accelerating glacial retreat and reducing terrestrial ice cover across much polar coastline (Doake \& Vaughan 1991, Serreze et al. 2000, Armstrong \& Brodzik 2001, Quayle et al. 2002). If such warming does reduce amounts of floating ice it will also drastically reduce disturbance to boulder fields. In such a situation our findings point to an eventual monopolisation of space by just 1 or 2 species. But, before that happens, our results suggest that we might expect an increase in regional diversity, as different mid-ranked species become more common from site to site with some reduction of disturbance. 
Acknowledgements. The authors wish to thank all the scientific staff and crew of the Polish Academy of Sciences RV 'Oceania'. We are also very grateful to Marcin Węsławski for the invitation to D.K.A.B. to join the 2002 East Spitsbergen cruise of Oceania.

\section{LITERATURE CITED}

Allen AP, Brown JH, Gillooly JF (2002) Global biodiversity, biochemical kinetics, and the energetic-equivalence rule. Science 297:1545-1548

Armstrong RL, Brodzik MJ (2001) Recent northern hemisphere snow extent: a comparison of data derived from visible and microwave sensors. Geophys Res Lett 28(19): 3673-3676

Austin MP (1999) A silent clash of paradigms: some inconsistencies in community ecology. Oikos 86:170-178

Barnes DKA (1999) The influence of ice on polar nearshore benthos. J Mar Biol Assoc UK 79:401-407

Barnes DKA (2002a) Polarization of competition increases with latitude. Proc R Soc Lond B 104:2061-2069

Barnes DKA (2002b) Polar punches and tropical truces. Planet Earth, winter 2002:5

Barnes DKA, Clarke A (1998) The ecology of an assemblage dominant: the encrusting bryozoan Fenestrulina rugula. Invertebr Biol 117:331-340

Barnes DKA, Dick MA (2000) Overgrowth competition between clades: implications for interpretation of the fossil record and overgrowth indices. Biol Bull 199:85-94

Barnes DKA, Kuklinski P (2003) High polar spatial competition: extreme hierarchies at extreme latitude. Mar Ecol Prog Ser 259:17-28

Brown JH, Davidson DW (1979) An experimental study of competition between seed eating desert rodents and ants. Am Zool 19:1129-1145

Buss LW, Jackson JBC (1979) Competitive networks: nontransitive competitive relationships in cryptic coral reef environments. Am Nat 113:223-234

Chornesky EA (1989) Repeated reversals during spatial competition between corals. Ecology 70:843-855

Clutton-Brock TH, Albon SD, Gibson RM, Guiness FE (1979) The logical stag: adaptive aspects of fighting in red deer (Cervus elaphus L.). Anim Behav 27:211-225

Connell JH (1961) The influence of interspecific competition and other factors on the distribution of the barnacles Chthamalus stellatus. Ecology 42:710-723

Connell JH (1978) Diversity in tropical rain forests and coral reefs. Science 199:1302-1310

Connell JH (1985) Variation and persistence of rocky shore populations. In: Moore PG, Seed R (eds) The ecology of rocky coasts. Hodder \& Stoughton, London, p 57-69

Convey P (2003) Maritime Antarctic climate change: signals from terrestrial biology. Antarct Res Ser 79:145-158

Convey P, Block W, Peat HJ (2003) Soil arthropods as indicators of water stress in Antarctic terrestrial habitats? Global Change Biol 9:1718-1730

Crame JA (2000) Evolution of taxonomic diversity gradients in the marine realm: evidence from the composition of recent bivalve faunas. Paleobiology 26:188-214

Darwin C (1859) On the origin of species. Murray, London

Dayton PK (1971) Competition, disturbance and community organisation: the provision and subsequent utilisation of space in a rocky intertidal community. Ecol Monogr 41: 351-389

Dayton PK (1990) Polar benthos. In: Smith WO (ed) Polar oceanography. Academic Press, London, p 631-685
Diamond JM (1987) Competition among different taxa. Nature 326:241

Doake CSM, Vaughan DG (1991) Rapid disintegration of the Wordie ice shelf in response to atmospheric warming. Nature 350:328-330

Dunton KH (1992) Arctic biogeography: the paradox of the marine benthic fauna and flora. Trends Ecol Evol 7(6): 183-189

Fowbert JA, Smith RIL (1994) Rapid population increases in native vascular plants in the Argentine Islands, Antarctic Peninsula. Arct Alp Res 26:290-296

Gutt J (2001) On the direct impact of ice on marine benthic communities, a review. Polar Biol 24:553-564

Gutt J, Starmans A, Dieckmann G (1996) Impact of iceberg scouring on polar benthic habitats. Mar Ecol Prog Ser 137: 311-316

Hansen J, Ruedy R, Glascoe J, Sato M (1999) GISS analysis of surface temperature change. J Geophys Res 104: 30997-31022

Hochberg ME, Lawton JH (1990) Competition between kingdoms. Trends Ecol Evol 5:367-370

Jackson JBC (1979) Morphological strategies of sessile animals. In: Larwood G, Rosen GR (eds) Biology and systematics of colonial organisms. Academic Press, London, p 499-555

Jackson JBC, Buss L (1975) Allelopathy and spatial competition among coral reef invertebrates. Proc Natl Acad Sci 72: $5160-5163$

Karlson RH (1983) Disturbance and monopolisation of a spatial resource by Zooanthus sociatus. Bull Mar Sci 33: 118-131

Karlson RH (1999) Dynamics of coral communities. Kluwer Academic, Dordrecht

Karlson RH, Cornell HV (1998) Scale-dependent variation in local vs regional effects on coral species richness. Ecol Monogr 68:259-274

Karlson RH, Jackson JBC (1981) Competitive networks and community structure: a simulation study. Ecology 62: $670-678$

Kolding S (1986) Interspecific competition for mates and habitat selection in 5 species of Gammarus (Amphipoda: Crustacea). Mar Biol 91:491-495

Kuklinski P (2001) Bryozoa of the high arctic fjord-a preliminary study. In: Wyse Jackson P, Buttler C, Spencer Jones M (eds) Bryozoan studies 2001. Balkema, Abingdon, p 175-182

MacArthur RH (1972) Geographical ecology. Harper \& Row, New York

Maughan B (2000) Ecology of encrusting epifauna at Lough Hyne marine nature reserve, Co. Cork, Ireland. PhD thesis, University College Cork

Maughan B, Barnes DKA (2000) Seasonality of competition in early development of subtidal encrusting communities. PSZN I Mar Ecol 21:205-220

McKinney FK, Lidgard S, Sepkoski JJ, Taylor PD (1998) Decoupled temporal patterns of evolution and ecology in 2 post-paleozoic clades. Science 281:807-809

Menge BA, Sutherland JP (1987) Community regulation: variation in disturbance, competition and predation in relation to environmental stress and recruitment. Am Nat 130: 730-757

Murphy JM, Mitchell JFB (1995) Transient response of the Hadley Centre coupled ocean-atmosphere model to increasing carbon dioxide. J Clim 8:36-514

Nandakumar K (1995) Competitive interactions among sessile organisms in Tomioka Bay, south Japan: importance of light conditions on the panel surface. Mar Biol 121:713-719 
Newsham KK, Hodgson DA, Murray AWA, Peat HJ, Smith RIL (2002) Response of 2 Antarctic bryophytes to stratospheric ozone depletion. Global Change Biol 8:972-983

Paine RT (1974) Intertidal community structure: experimental studies on the relationship between a dominant competitor and its principal predator. Oecologia 15:710-719

Paine RT (1979) Disaster, catastrophe, and local persistence of the sea palm Postelsia palmaeformis. Science 205:685-687

Quayle W, Peck LS, Peat HJ, Ellis-Evans JC, Harrigan PR (2002) Extreme responses to climate change in antarctic lakes. Science 295:645

Quinn JF (1982) Competitive hierarchies in marine benthic communities. Oecologia 54:129-135

Roughgarden J (1986) A comparison of food-limited and space-limited animal competition communities. In: Diamond J, Case TJ (eds) Community ecology. Harper \& Row, New York, p 492-516

Roy K, Jablonski D, Valentine JW, Rosenberg G (1998) Marine latitudinal diversity gradients: tests of causal hypotheses. Proc Nat Acad Sci USA 95:3699-3702

Russ GR (1982) Overgrowth in a marine epifaunal community: competitive hierarchies and competitive networks. Oecologia 53:12-19

Schoener TW (1983) Field experiments on interspecific competition. Am Nat 122:240-285

Sebens KP (1986) Spatial relationships among encrusting marine organisms in the New England subtidal zone. Ecol Monogr 56:73-96

Editorial responsibility: Otto Kinne (Editor),

Oldendorf/Luhe, Germany
Serreze MC, Walsh JE, Chapin FSIII, Osterkamp T and 6 others (2000) Observational evidence of recent change in the northern high-latitude environment. Clim Change 46: $159-207$

Swerpel S (1985) The Horsund Fiord: water masses. Pol Polar Res 6(4):475-496

Tanaka M, Nandakumar K (1994) Measurement of the degree of intransitivity in a community of sessile organisms. J Exp Mar Biol Ecol 182:85-95

Tanner JE (1997) Interspecific competition reduces fitness in scleractinian corals. J Exp Mar Biol Ecol 214:19-34

Todd CD, Turner SJ (1988) Ecology of sublittoral cryptic epifaunal assemblages. II. Non-lethal overgrowth of encrusting bryozoans by colonial ascidians. J Exp Mar Biol Ecol 74:113-126

Turner SJ, Todd CD (1994) Competition in encrusting bryozoan assemblages: the influence of encounter angle, site and year on outcome variability. J Mar Biol Assoc UK 74: $603-622$

Walther GR, Post E, Convey P, Menzel A and 5 others (2002) Ecological responses to recent climate change. Nature 416: 389-395

Węsławski JM, Zajączkowski M, Kwaśniewski S, Jezierski J, Moskal W (1988) Seasonality in an Arctic fjord ecosystem: Horsund, Spitsbergen. Polar Res 6:185-189

Węsławski JM, Wiktor J, Zajączkowski M, Swerpel S (1993) Intertidal zone of Svalbard 1. Macroorganism distribution and biomass. Polar Biol 13:73-79

Submitted: September 2, 2003; Accepted: Febraury 17, 2004 Proofs received from author(s): June 7, 2004 